\title{
ISLAM DAN FILSAFAT PERENIAL: RESPON SEYYED HOSSEIN NASR TERHADAP NESTAPA MANUSIA MODERN
}

\author{
Fathin Fauhatun \\ Institut Agama Islam Negeri (LAIN) Bukittinggi,ffaubatun@gmail.com

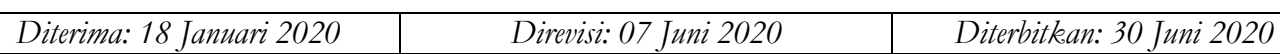

\begin{abstract}
This paper examines Seyyed Hossein Nasr's thoughts on Islam and perennial philosophy in dealing with the problems of modern humans. The purpose of this article is to explain the plight of modern bumans and to explain how to overcome this problem through a study of the thoughts of a contemporary Muslim figure, namely Seyyed Hossein Nasr. In Nasr's perspective, perennial philosophy is a philosophy of eternity which is also interpreted as traditional wisdom. This thought about Nasr's perennial philosophy emerged as a critical reaction to what he saw as a crisis in modern humans. Modern civilization in the West which also flourished in the Islamic world, according to Nasr, has failed to achieve its goals because it has caused a variety of existentialism and spiritual crises experienced by modern humans. Through perennial philosophy, Nasr explained that to deal with the problems currently faced by modern humans is to get closer to God through Sufism as has been done by ancient scholars.
\end{abstract}

Keywords: Perennial Philosophy, Seyyed Hossein Nasr, Modern Man, Sufism.

\begin{abstract}
Abstrak
Tulisan ini mendedah pemikiran Seyyed Hossein Nasr tentang Islam dan filsafat perenial dalam menghadapi persoalan-persoalan manusia modern. Tujuan artikel ini untuk menjelaskan nestapa manusia modern dan dan mengemukakan bagaimana cara untuk mengatasi persoalan tersebut melalui studi terhadap pemikiran seorang tokoh Muslim kontemporer, yakni Seyyed Hossein Nasr. Dalam perspekti Nasr, filsafat perenial adalah filsafat keabadian yang juga diartikan sebagai kearifan tradisional. Pemikiran mengenai filsafat perenial Nasr ini muncul sebagai reaksi kritis terhadap apa yang dilihatnya sebagai krisis manusia modern. Peradaban modern di Barat yang juga berkembang di dunia Islam, menurut Nasr, telah gagal mencapai tujuannya karena justru menimbulkan beragam krisis eksistensialisme dan spiritual yang dialami manusia modern. Melalui filsafat perenial, Nasr menjelaskan bahwa untuk mengahadapi persoalan yang sedang dihadapi oleh manusia modern ialah dengan kembali mendekatkan diri kepada Tuhan melalui tasawuf seperti halnya yang telah dilakukan oleh ulama-ulama zaman dahulu.
\end{abstract}

Kata Kunci: Filsafat Perenial, Seyyed Hossein Nasr, Manusia Modern, Tasawuf. 


\section{PENDAHULUAN}

Sebuah kenyataan yang harus diterima bahwa efek dari modernisasi yang telah dihembuskan sejak masa Renaisans Barat telah menimbulkan ekses negatif pada krisis makna hidup, kehampaan spiritual, dan tergusurnya agama di dalam kehidupan manusia. ${ }^{1}$

Modernisasi yang bergandeng tangan dengan sekularisasi telah menghadirkan wajah sebagaiamna berikut: penyingkirkan agama dari kehidupan manusia seperti: menghilangkan nilainilai agama dan spiritual dalam melihat alam semesta, menyingkiran aspek rohani dan agama dari pergolakan politik, serta menghapus kesakralan nilai-nilai agama dari kehidupan. Sehingga akibat yang ditimbulkan dari proses sekularisasi ini adalah manusia menjadi lebih mementingkan kehidupan duniawi daripada spiritual. Kehidupan manusia dari berbagai aspek seperti perkembangan ilmu pengetahuan, masyarakat, politik dan lain sebagainya telah terpisah dari hal-hal yang berkaitan dengan agama dan nilai-nilai spiritual yang membuat manusia modern hidup dalam kehampaan spiritual. ${ }^{2}$

Di zaman modern, banyak pembahasan yang mengulas tentang kelebihan penduduk atau polusi air dan udara. Tetapi hasil dari pembahasan mengenai persoalan tersebut, hanya berbicara mengenai perlunya pembangunan lebih lanjut. Manusia hanya membahasa mengenai bagaimana langkah yang harus dilakukan untuk melawan penderitaan manusia akibat keadaan yang dipaksakan oleh kehidupan di bumi. Mereka hanya melihat persoalan yang tampak saja tanpa melihat apa penyebab di balik persoalan tersebut. Hanya sedikit manusia yang menyadari bahwa persoalan sosial dan teknologi yang paling akut itu

1 Ali Maksum, Tasawnf Sebagai Pembebasan Manusia Modern: Telaah Signifikansi Konsep "Tradisionalisme Islam" Sayyed Hossein Nasr (Yogyakarta: Pustaka Pelajar, 2003), 69.

2 Dedy Irawan, "Tasawuf Sebagai Solusi Krisis Manusia Modern: Analisis Pemikiran Seyyed Hossein Nasr," Tasfiyah 3, no. 1 (February 2019): 42-43, https://doi.org/10.21111/tasfiyah.v3i1.2981; Lihat juga Zulfan Taufik, Dialektika Islam Dan Humanisme (Tangerang Selatan: Onglam Books, 2015), 3-4. muncul disebabkan oleh pembangunan yang berlebihan bukan karena ketertinggalan pembagunan dan runtuhnya keseimbangan antara manusia dan alam, sehingga mengakibatkan penaklukan dan dominasi manusia terhadap alam. Hanya sedikit orang yang mau menerima kenyataan bahwa perdamaian dalam masyarakat akan terwujud jika manusia mau mengambil langkah untuk berdamai dengan alam bukan dengan melakukan pembangunan yang berlebihan sehingga berdampak bagi kerusakan alam. Dan tidak semua orang pula menyadari bahwa untuk berdamai dengan alam, manusia juga harus berdamai dengan tatanan spiritual. Bukan dengan menghilangkan nilai-nilai spiritual seperti yang terjadi di zaman sekarang. ${ }^{3}$

Seyyed Hossein Nasr merupakan seorang pemikir kontemporer yang dengan tegas mengemukakan pendapatnya, baik itu di kalangan Timur maupun Barat. Ia jarang mendapatkan tantangan ketidaksetujuan karena logika yang ia gunakan dalam mengungkapkan pemikirannya jelas. Ia juga mampu mengungkapkan pemikirannya dengan menggunakan bahasa dan logika yang mudah untuk dipahami. Untuk membangun kesadaran bersama mengenai perlukan rasa aman dan damai, Nasr dalam karyakaryanya berusaha menggabungkan antara dimensi spiritual dan dimensi rasional agar menjadi layak untuk dikembangkan di zaman modern ini. ${ }^{4}$

Seyyed Hossein Nasr menaruh perhatiannya mengenai tawaran alternatif untuk penyembuhan krisis spiritual manusia modern. Untuk menghadapi persoalan tersebut, menurutnya, manusia perlu kembali menghidupkan nilai-nilai tradisional seperti tasawuf, tradisi yang sesuai dengan nilai-nilai Islam, dan kehidupan sosial dalam bermasyarakat yang sesuai dengan nilai-nilai keislaman. Lebih

3 Seyyed Hossein Nasr, Terj. Ali Noer Zaman, Antara Tuhan, Manusia Dan Alam (Yogyakarta: IRCiSoD, 2003), 20.

${ }^{4}$ Jaipuri Harahap, "Sayyed Hossein Nasr Tentang Filsafat Perennial Dan Human Spiritualitas," Aqlania 8, no. 2 (December 2017): 175. 
lanjut menurut Nasr, krisis-krisis eksistensialisme maupun spiritual yang dialami oleh manusia modern yaitu ketika manusia mulai meninggalkan Tuhan dalam kehidupannya demi mengukuhkan eksistensi dirinya. Hal ini mengakibatkan manusia malah kehilangan jati diri dan bergerak menuju pinggiran eksistensinya. ${ }^{5}$ Kejadian ini tidak hanya dialami oleh Barat tetapi juga dialami oleh dunia Islam. Kesalahan-kesalahan yang telah dilakukan Barat telah diulang kembali oleh hampir seluruh Negara di Timur, yaitu dengan menciptakan masyarakat kota industri dan peradaban modern. Seharusnya Timur dapat menjadikan Barat sebagai sebuah studi kasus bukan sebaliknya menjadikan sebuah kesalahan sebagai teladan yang harus dicontoh tanpa melakukan pengkajian ulang terlebih dahulu, alias hanya menerima begitu saja. ${ }^{6}$

Di dunia Islam pada masa kini terdapat berbagai macam kelompok yaitu: kelompok tradisional, kelompok yang berada di antara nilainilai tradisional dan nilai-nilai modern, kelompok modern, namun seluruh kelompok ini masih hidup didalam pertumbuhan Islam. ${ }^{7}$ Persoalanpersoalan yang muncul dalam dunia Islam yaitu dilema-dilema yang dihadapi kaum Muslimin di dalam hubungan mereka dengan dunia modern. Permasalahan yang tengah dihadapi yaitu kaum Muslim terombang-ambing di dalam dua kekuatan; di satu pihak kekuatan tradisi Islam, di lain pihak kekuatan sekularisme dan modernisme. $^{8}$

Sejak berawalnya revolusi pemikiran yang dipelopori oleh Descartes dengan mengajukan argumentasi epistimologis mengenai akar kebenaran adalah akal, maka pada saat itu terjadilah pemisahan antara yang imanen dan transenden. Manusia menganggap dirinya sebagai super being (makhluk super) yang mampu

5 Hanna Widayani, "Pemikiran Sayyid Hossein Nasr Tentang Filsafat Perennial," EL-AFKAR: Jurnal Pemikiran Keislaman Dan Tafsir Hadis 1, no. 6 (2017): 55.

${ }^{6}$ Seyyed Hossein Nasr, Islam Dan Nestapa Manusia Modern (Bandung: Pustaka, 1983), 21.

${ }^{7}$ Nasr, Islam Dan Nestapa Manusia Modern.

8 Nasr. menyelesaikan seluruh persoalan yang dihadapinya dengan akal serta menjadikan teknologi sebagai alat yang paling ampuh dalam mengatasi segala persoalan kemanusiaan. Manusia modern semakin kehilangan unsur keinsaniannya karena telah menggantungkan dirinya pada eksistensi kebendaan yang bersifat relatif dan nisbi yang notabenenya adalah unsur yang memiliki tingkat kesempurnaan di bawah manusia sehingga ketidakbebasan telah melingkupi manusia. Padahal menurut kaum perenial, pada dasarnya kebebasan manusia terwujud apabila manusia terbebas dari sesuatu yang berkaitan dengan materi dan bergantung pada keabsolutan Tuhan. $^{9}$

Dalam pandangan Islam, manusia adalah theophany (pancaran) dari nama-nama dan kualitas Tuhan, dan juga sebagai khalifahnya di muka bumi serta berpartisipasi dalam kebebasan Tuhan. Kebebasan manusia telah mendustakan kenyataan dalam penyerahan atas kehendaknya, upaya untuk mengatasi persoalan yang mendesak, dan membatasi kebebasan manusia adalah dengan pembersihan bathin agar manusia menjadi bebas dari segala kondisi luar termasuk nafsu badani.

Spiritualitas merupakan kebutuhan manusia masa kini, dan merupakan kebutuhan permanen bagi manusia. Untuk meningkatkan semangat spiritual dalam Islam, Tuhan tidak hanya dijadikan sebagai penguasa alam, namun juga merupakan pusat bertumpunya suatu hal yang dimulai dan diakhiri dengan tujuan semangat spiritual tersebut. Setiap dimensi dalam kehidupan senantiasa menjadikan Tuhan sebagai objek yang dikelilingi dan segala sesuatu berpusat padanya sebagai sebuah proses pencarian dengan tujuan mencapai eksistensi kemanusiaan. Pandangan demikian merupakan sebuah warisan lama yang telah banyak dilupakan oleh manusia di zaman modern. Manusia di zaman modern sudah mulai mengabaikan bahkan tidak mengetahui lagi

9 Arqom Kuswanjono, "Filsafat Perennial Dan Rekonstruksi Pemahaman Keberagamaan," Jurnal Filsafat Special Ed (1997): 96-97, https://doi.org/https://doi.org/10.22146/jf.31778. 
akan nilai-nilai kearifan tradisional. Kearifan tradisional inilah merupakan ciri khas yang dibahas dalam filsafat perenial dimana dalam filsafat perenial ini berusaha untuk membangkitkan kembali kearifan tradisional yang telah banyak dilupakan, padahal dalam kearifan tersebut terletak kebahagiaan dan juga keselamatan manusia. Oleh karena itu, pembahasan dalam filsafat perenial ini bertujuan untuk memulihkan kembali spiritual masyarakat di zaman modern. ${ }^{10}$

Dalam menghadapi segala realita yang mulai muncul dan berkembang di zaman modern, Nasr memberikan tawaran sebuah solusi baru untuk memecahkan permasalahan yang disebut dengan filsafat perenial. Filsafat perenial merupakan suatu pembahasan dalam filsafat yang berusaha membangkitkan kesadaran manusia bahwa sebenarnya Tuhanlah wujud yang absolut dan merupakan pemilik dari segala yang tampak. Filsafat perenial juga membahas mengenai fenomena pluralisme agama dan berusaha menelusuri akar-akar kesadaran religiusitas melalui symbol-simbol, ritus, serta pengalaman keberagamaan. ${ }^{11}$

Tulisan ini lebih jauh megengksplor pemikiran-pemikiran Seyyed Hossein Nasr mengenai krisis yang terjadi pada zaman modern. Tema ini menjadi penting untuk dibahas karena dalam pemikirannya Nasr mengemukakan cara yang efektif untuk kembali memulihkan kondisi spiritual kaum Muslim akibat kuatnya pengaruh perubahan yang terjadi di zaman modern yang menjadikan umat Muslim kehilangan jati dirinya. yang membuatnya mudah diserang berbagai penyakit rohani, serta membuat mereka menjadi lupa tentang siapa dirinya, untuk apa hidup ini, serta kemana sesudahnya.

Seyyed Hossein Nasr merupakan seorang pemikir Muslim yang telah menguasai berbagai

10 Kuswanjono, "Filsafat Perennial Dan Rekonstruksi Pemahaman Keberagamaan.”

11 Komaruddin Hidayat and M. Wahyuni Nafis, Agama Masa Depan: Perspektif Filsafat Perennial (Jakarta: Paramadina, 1995), 1. macam disiplin ilmu. Gagasan-gagasannya mengenai Islam, filsafat perenial, dan modernisme tampak dalam beberapa karyanya sehingga di dalam peta pemikiran keislaman, Nasr diposisikan sebagai seorang pemikir yang populer. Nasr mampu memadukan antara dimensi fisik dan spiritual ketika ia mendekati seluruh objek yang ia teliti.

Popularitas pemikiran Nasr tampak dari ragam kajian yang telah membedah pemikirannya. Di antara beberapa hasil kajian tersebut antara lain Hanna Widayanti ${ }^{12}$ dan Jaipuri Harahap ${ }^{13}$ yang mengupas terkait pemikiran filsafat perenial Nasr untuk melihat krisis yang terjadi pada manusia modern. Fitri Siska Supriatna dan Salman Husain ${ }^{14}$ mengulas tentang kritikan terhadap perkembangan sains di zaman modern dengan melihat kontribusi filsafat perennial terhadap hal tersebut. Adapun Tri Astutik Haryati $^{15}$ membahas tentang modernitas perspektif Nasr. Dalam penelitian ini dijelaskan dalam membahas mengenai modernitas Nasr berhadapan dengan dua pandangan metafisik yaitu barat dan timur. Berbeda dengan kajian sebelumnya tersebut, kajian dalam artikel ini merupakan penelitian kepustakaan yang berusaha merumuskan ide-ide dari Nasr terkait dengan Islam dan filsafat perenial sebagai respn atas problematika manusia modern. Dalam pembahasan ini, penulis mengumpulkan beberapa karya-karya Nasr terkait dengan pembahasan ini, dalam tulisan ini penulis akan memaparkan mengenai islam dan filsafat perennial, problemproblem yang dihadapi oleh manusia di zaman modern dan solusi yang ditawarkan oleh nasr untuk menghadapi persoalan tersebut.

12 Widayani, "Pemikiran Sayyid Hossein Nasr Tentang Filsafat Perennial."

13 Harahap, "Sayyed Hossein Nasr Tentang Filsafat Perennial Dan Human Spiritualitas."

14 Fitri Siska Supriatna and Salman Husain, "Kontribusi Filsafat Perenial Sayyed Hossein Nasr Terhadap Sains Modern," in Prosiding Konferensi Integrasi Interkoneksi Islam Dan Sains, vol. 2, 2020, 177-83.

15 Tri Astutik Haryati, "Modernitas Dalam Perspektif Seyyed Hossein Nasr," Jurnal Penelitian 8, no. 2 (2012), https://doi.org/10.28918/jupe.v8i2.84. 
Metode yang digunakan dalam kajian ini adalah library research. Kajian ini merupakan kajian yang bersifat filosofis terhadap pemikiran seorang tokoh. Maka pendekatan yang digunakan dalam penulisan ini adalah pendekatan filsafat. Salah satu ciri khas pendekatan filsafat yaitu pengkajian dan penelitian struktur ide-ide dasar serta pemikiran fundamental yang dirumuskan seorang pemikir. $^{16}$

Agar pembahasan yang akan dikaji lebih terarah maka sistematika yang akan dibahas dalam kajian ini yaitu, membahas tentang pengenalan singkat Nasr dan karya-karya nya, Islam dan filsafat perenial dengan mengungkapkan pemikiran Nasr dan juga pembahasan lain terkait dengan pembahasan ini, nestapa manusia modern, serta pemaparan tentang solusi yang ditawarkan Nasr untuk menghadapi persoalanpersoalan yang sedang dihadapi manusia di zaman modern melalui sufisme.

\section{MENGENAL SEYYED HOSSEIN NASR}

Seyyed Hossein Nasr lahir pada tanggal 17 April 1933 di kota Teheran Republik Islam Iran. Ayahnya bernama Seyyed Waliyullah Nasr yang berprofesi sebagai ulama, dokter, dan pendidik. Seyyed Hossein Nasr menjalani pendidikan dasar di kota kelahirannya Teheran. Kemudian ia dikirim ke kota Qum oleh ayahnya untuk belajar pada sejumlah ulama besar dalam berbagai bidang pengetahuan seperti filsafat, ilmu kalam, tasawuf, menghafal al-Qur'an dan syair-syair klasik.

Nasr dikirim ke Barat untuk mengikuti pendidikan tingkat atas pada usia 13 tahun dan kemudian melanjutkan pendidikannya di Universitas Massachusetts Institute of Technologi di bawah bimbingan seorang filosof Betrand Russel. Selain itu ia juga belajar filsafat Muslim di bawah bimbingan George de Santilana. Nasr melanjutkan pendidikannya di Harvard University untuk mendalami pelajaran geologi dan geofisika pada tahun 1954. Kemudian Nasr beralih pada

16 Anton Bakker and A. Charris Zubair, Metodologi Penelitian Filsafat, Pustaka Filsafat (Yogyakarta: Penerbit Kanisius, 1994), 46. bidang ilmu-ilmu tradisional yang difokuskan pada Islamic science dan filsafat. ${ }^{17}$

Bebrapa kondisi yang mempengaruhi pemikiran Nasr yaitu:

\section{a. Kondisi Politik}

Menelusuri tempat arus pemikiran politik Islam, apabila Persia ditarik ke dalam dunia Asia, Iranlah yang memungkinkan hal itu. Ini dibuktikan dengan meletusnya revolusi Islam di Iran. Tahun 1979 merupakan revolusi Islam di Iran, sedangkan pada tahun 1905 terjadi revolusi Persia terhadap Bani Qajar. Selama periode Bani Qajar, kaum ulama Syi'ah telah memainkan peran penting dalam kehidupan umum dan memelihara hak-hak istimewa yang telah mapan.

Pada saat pemerintahan dipimpin oleh Pahlevi (1925-1978), agama dan juga para ulama pasif dan jauh dari politik, hal ini karena agama dikendalikan secara hati-hati. Dampak modernisasi yang luas dari program modernisasi Pahlevi hanya dapat dirasakan oleh sekelompok minoritas elite tertentu, dan kemilaunya kota modern menutupi kondisi aktual kaum urban yang miskin dan masyarakat desa iran. Perasaan kecewa mulai tumbuh dan menyebar di kalangan masyarakat luas pada tahun 1970-an. Keprihatinan akan intervensi asing dan ketergantungan pada Barat tidak hanya dirasakan oleh sekelompok tradisional tetapi juga oleh generasi terpelajar modern yang mengetahui politik di Iran, dengan demikian, kondisi politik masa Pahlevi menyiratkan usaha sistematis meminggirkan peran ulama dalam kehidupan politik dan perannya di masyarakat. ${ }^{18}$

\section{b. Kondisi Sosial Budaya}

Pada masa Reza Syah dan Muhammad Reza Syah Pahlevi kehidupan sosial budaya mengalami pergeseran yang cukup tajam, yaitu bergerak ke arah sekuler. Kehidupan masyarakat Iran yang sudah kental dengan religius-spiritual

17 Harahap, "Sayyed Hossein Nasr Tentang Filsafat Perennial Dan Human Spiritualitas."

18 Ahmad Hasan Ridwan, Dasar-Dasar Epistemologi Islam (bandung: CV Pustaka Setia, 2011), 305-306. 
mulai diarahkan pada hal-hal yang bersifat materialis sekuler. Syah sangat berambisi untuk memajukan negerinya dengan mengadakan modernisasi dalam segala bidang walaupun harus mengorbankan sosio-kultural yang lama untuk diganti dengan yang baru atau dengan kata lain westernisasi. Dengan kecendrungan itu Syah Iran menjadi simbol kafir bagi Muslim Iran.

Ambisi Reza Syah adalah untuk menandingi teman imbangannya dari Turki, yaitu Mustafa Kemal. Ia ingin memperkuat negerinya dengan cara memakai teknologi dan pembaharuan Barat. Pembaharuan yang dilakukan Reza bukan hanya sebatas pada teknologi tapi juga dalam lapangan sosial dan pendidikan, dengan menghilangkan pendidikan agama di sekolah-sekolah dasar dan menengah. ${ }^{19}$

Pemikiran-pemikiran Seyyed Hossein Nasr mengenai krisis yang terjadi pada zaman modern penting untuk dibahas, karena dalam pemikirannya Nasr mengemukakan cara yang efektif untuk kembali memulihkan kondisi spiritual kaum Muslimin akibat kuatnya pengaruh perubahan yang terjadi di zaman modern yang menjadikan umat Muslim kehilangan jati dirinya. Kehidupan modern juga membuat manusia mudah diserang oleh berbagai penyakit rohani, manusia juga menjadi lupa untuk apa dia hidup dan kemana tujuannya.

Nasr sangat menyesalkan banyak umat Islam mengikuti sikap dan pola pikir Barat. Bagi Nasr, kebebasan manusia yang sebenarnya adalah kesadaran akan hubungan dasar antara dirinya dan Allah SWT, seperti yang sudah sering dibahas dan dijelaskan dalam filsafat dan tasawuf Islam. Nasr meyakini ilmu pengetahuan yang benar adalah ilmu pengetahuan yang mengetahui hubungan antara yang duniawi dan ukhrawi. Sebagai seorang muslim Syi'ah, Nasr menaruh perhatian khusus pada pemikiran syi'ah dan pengungkapan nilai rohani yang banyak dipaparkannya dalam sejumlah buku yang ditulisnya, seperti dalam buku Ideals and Realities of

${ }^{19}$ Ridwan, Dasar-Dasar Epistemologi Islam.
Islam, Man and Nature: The Spiritual Crisis of Modern Man, Islam and the Plight of Modern Man dan Islamic Art and Spirituality. ${ }^{20}$ Nasr adalah penganut filsafat perennial, hal ini terlihat dalam bukunya yang berjudul Knowledge and the Sacred, Nasr juga menulis sebuah buku yang berjudul Islam and the Perennial philosophy, Scientia Sacra.

\section{ISLAM DAN FILSAFAT PERENNIAL}

Melihat definisinya, perenial Secara etimologis berasal dari bahasa latin yaitu perennis, yang berarti kekal atau abadi. Sehingga filsafat perennial dapat dikatakan sebagai filsafat keabadian. ${ }^{21}$ Sebagai sebuah istilah, Seyyed Hossein Nasr menyebut bahwa perenial pada mulanya digunakan di Barat yang terdapat dalam sebuah buku berjudul De Perenni Philosopbia pada tahun 1540 dan penulis buku ini adalah Agostino Steuco. Selanjutnya pada tahun 1715, istilah tersebut dipopulerkan oleh Leibniz dalam suratnya, yang menjelaskan bahwa yang dimaksud dengan filsafat perennial adalah filsafat yang berbicara mengenai pemisah antara yang gelap dan yang terang. Berbeda dengan apa yang disebutkan oleh Nasr, Aldous Huxley menyebutkan bahwa yang pertama kali menyebutkan istilah filsafat perennial itu adalah Leibniz. $^{22}$

Selanjutnya, dalam mengkaji agama secara perenial akan diungkapkan beberapa persoalan antara lain: pertama, mengungkapkan mengenai Tuhan sebagai wujud absolut yang merupakan sumber dari segala yang wujud, Tuhan yang maha benar atau sang pemilik kebenaran hanya satu sehingga pada prinsipnya semua agama berasal dari sumber yang sama. Kedua, perenial berusaha mengkaji secara kritis mengenai pluralism agama.

20 Syarif Hidayatullah, "Konsep Ilmu Pengetahuan Syed Hussein Nashr: Suatu Telaah Relasi Sains Dan Agama," Jurnal Filsafat 28, no. 1 (February 2018): 124, https://doi.org/10.22146/jf.30199.

21 Kuswanjono, "Filsafat Perennial Dan Rekonstruksi Pemahaman Keberagamaan."

22 Zulfan Taufik, Wajab Perenial Sufisme Di Perkotaan Indonesia Kontemporer (Tangerang Selatan: Onglam Books, 2017), 50. 
Pada dasarnya kebenaran dalam agama itu hanyalah satu, meskipun agama $\mathrm{A}$ dan $\mathrm{B}$ masingmasing memiliki kebenaran, hal ini karena agama diturunkan kepada manusia dalam bentuk yang fitrah dan pluralistik. ${ }^{23}$ Istilah Pluralisme sendiri merupakan kata yang ampuh dan juga ringkas untuk membicarakan suatu tatanan baru dimana perbedaan baik dari segi budaya, nilai-nilai maupun sistem kepercayaan, perlu untuk disadari agar manusia dapat hidup damai dalam perbedaan dan keragaman. ${ }^{24}$ Dari penjelasan tersebut setiap agama memiliki kesamaan dengan yang lain sekaligus juga memiliki kekhasannya sehingga berbeda dari yang lain. Ketiga, filsafat perenial berusaha menelusuri akar religious manusia melalui pengalaman keagamaan serta simbolsimbol ritus. Dari sini filsafat perennial disebut juga sebagai upaya menemukan kembali tradisi agama yang suci, serta berusaha untuk menyatakan kembali kebenaran yang merupakan pusat dan esensi tradisi. ${ }^{25}$

Secara sederhana filsafat perenial bisa diartikan suatu pandangan hidup yang sudah lama menjadi pegangan dan dipelihara oleh mereka para penganut al-hikmah, dalam istilah Kristen disebut para gnosis sementara dalam islam disebut para sufi, hal ini biasa dikenal sebagai nilai-nilai tradisional. Di dalam tradisi-tradisi esoterik terdapat pengetahuan dan juga pesanpesan keagamaan yang sama, namun hal tersebut muncul melalui perbedaan nama dan dikemas dalam berbagai bentuk dan simbol, inilah yang merupakan inti pandangan dari pembahasan filsafat perenial.

Terdapat penyebutan yang berbeda-beda pada setiap agama, ada yang disebut Sanatana Dharma terdapat dalam agama Hindu dan Budha,

23 Rusdin, "Kebenaran Agama Dalam Filsafat Perennial (Perspektif Seyyed Hossein Nasr)," Rausyan Fiker 14, no. 2 (2018): 253.

24 Busyro Busyro, Aditiya Hari Ananda, and Tarihoran Sanur Adlan, "Moderasi Islam (Wasathiyyah) Di Tengah Pluralisme Agama Indonesia," FUADUNA : Jurnal Kajian Keagamaan Dan Kemasyarakatan 3, no. 1 (November 2019): 3, https://doi.org/10.30983/fuaduna.v3i1.1152.

25 Rusdin, "Kebenaran Agama Dalam Filsafat Perennial (Perspektif Seyyed Hossein Nasr).” yaitu merupakan akar kebijakan abadi agama tersebut dalam menghadapi segala situasi, sehingga menjadikan agama selalu memanifestasikan diri secara etis dalam keluhuran hidup manusia. Dalam Islam terdapat kata al-din yang memiliki arti ikatan, kata al-din merupakan akar dalam beragama bagi umat Islam. Namun perbedaan nama dan kemasan hanya merupakan jalan yang membuat manusia terbebas dari ikatanikatan dunia materi yang dapat menyengsarakan kehidupan manusia, bukan merupakan suatu tujuan hanya sebagai sebuah jalan untuk mencapai tujuan. ${ }^{26}$

Perkembangan metafisik dalam bentuk filsafat perennial, dibawah pimpinan Rene Guenon dan juga murid-muridnya seperti Fritjof Schuon dan Martin Lings, mereka adalah generasi intelektual baru di Barat yang mulai tersadar dari kematian spiritual yang terjadi di Barat, mereka mencoba mencari solusi untuk mengatasi kematian spiritual tersebut dengan cara merumuskan secara kreatif metafisika sebagai alternatif untuk mengatasi materialistik di Barat. Penting untuk diketahui bahwa mereka mengadopsi tradisi-tradisi agama besar di Timur sebagai sumber inspirasi bagi mereka, termasuk Islam dalam bentuk sufismenya. ${ }^{27}$

Filsafat perenial ini penting untuk memahami ajaran-ajaran keagamaan atau spiritual masyarakat kuno. Selain itu, filsafat perenial menjadi sumber yang kaya bagi wacana-wacana yang sedang populer saat ini, seperti wacana tentang pluralisme atau inklusivisme dalam permasalahan ini filsafat perenial banyak memberi ide-ide mengenai hubungan agama-agama dan cara mengatasi krisis manusia modern dengan penekanan pada aspek esoterik dari ajaran-ajaran agama. ${ }^{28}$

${ }^{26}$ Hidayat and Nafis, Agama Masa Depan: Perspektif Filsafat Perennial.

27 Mulyadhi Kartanegara, Gerbang Kearifan: Sebuah Pengantar Filsafat Islam (Jakarta: Lentera Hati, 2006), 173-174.

28 Kartanegara, Gerbang Kearifan: Sebuah Pengantar Filsafat Islam, 176-177. 
Dalam agama Islam terdapat doktrin tentang tauhid, hal ini juga merupakan ruang lingkup kajian kaum perenialis. Setelah mengkaji lebih lanjut tentang tauhid para pendukung perennialis berpendapat, ternyata pesan yang terdapat didalam ajaran tauhid tidak seluruhnya secara eksklusif esensi pesan didalamnya hanya milik Islam, melainkan terlebih merupakan hatinya setiap agama. Mengenai doktrin tentang tauhid didalam Islam pemaknaan tentang konsep pewahyuan merupakan suatu penegasan, oleh karenanya, hal yang serupa mengenai doktrin tentang tauhid ini ditemukan dalam setiap agama. $^{29}$

Hampir seluruh bidang kajian tasawuf dalam Islam kental dengan tradisi perenial. Nasr berpendapat bahwa orang-orang suci terdahulu banyak mempengaruhi kajian tasawuf dalam Islam. Islam berpandangan, banyak orang suci yang hidup sebelum dan juga setelah Muhammad, pada dasarnya dari sisi ajaran agama yang dibawa oleh Muhammad bukanlah baru, melainkan sebagai pelengkap dan penegasan kembali dari ajaran agama yang telah dibawa oleh para utusan Tuhan sebelumnya. Al-Din yang berarti ikatan, merupakan ikatan yang mengikat manusia dengan Tuhannya, ikatan yang dapat membebaskan manusia dari sesuatu yang didominasi oleh sesuatu yang derajatnya lebih rendah dari manusia. Jika manusia mengabaikan perhatiannya pada yang mutlak dan lebih mengfokuskan perhatiannya pada yang relatif, maka yang terjadi adalah jatuhlah derajat kemanusiaannya. ${ }^{30}$

Dalam pandangan Islam manusia adalah pancaran dari asma Allah dan juga kualitas Allah, diutusnya manusia ke bumi adalah sebagai khalifah-Nya serta berpartisipasi dalam kebebasan Tuhan. Dalam menyerahkan kehendak-Nya kepada manusia, kesucian bathin merupakan sebuah upaya yang bisa membuat manusia terbebas dari segala kondisi luar, namun kenyataannya saat ini kebebasan manusia telah

${ }^{29}$ Hidayat and Nafis, Agama Masa Depan: Perspektif Filsafat Perennial.

${ }^{30}$ Hidayat and Nafis. mendustakannya, termasuk pengaruh nafsu badani, yang mendesak dan membatasi kebebasan manusia. $^{31}$

Spiritualitas adalah kebutuhan manusia masa kini, seseorang yang memiliki spiritualitas tinggi adalah seseorang yang mengikutsertakan Tuhan sebagai yang terpenting dalam kehidupannya, yang menjadi penentu dan pedoman dalam bertindak dan bertingkah laku dalam kehidupan sehari-hari. ${ }^{32}$ Dalam mengartikan mengenai spiritual adalah memiliki pengetahuan, rasa cinta serta taat kepada Tuhan. Tuhan tidak hanya dijadikan sebagai penguasa alam, namun juga merupakan pusat bertumpunya segala sesuatu yang dimulai dan diakhiri dengan tujuan semangat spiritual. Setiap dimensi dalam kehidupan senantiasa menjadikan Tuhan sebagai objek yang dikelilingi, segala sesuatu berpusat padanya sebagai sebuah proses pencarian dengan tujuan mencapai eksistensi kemanusiaan. Pandangan demikian merupakan sebuah warisan lama yang telah banyak dilupakan oleh manusia di zaman modern, manusia di zaman modern sudah mulai mengabaikan bahkan tidak mengetahui lagi akan nilai-nilai kearifan tradisional, kearifan tradisional inilah merupakan ciri khas yang dibahas dalam filsafat perennial dimana dalam filsafat perennial ini berusaha untuk membangkitkan kembali kearifan tradisional yang telah banyak dilupakan, padahal dalam kearifan tersebut terletak kebahagiaan dan juga keselamatan manusia. ${ }^{33}$

Nasr merupakan penganut filsafat perennial yang merupakan paham bahwa terdapat suatu pengetahuan ilahi mendasar. Filsafat perennial tidak memungkiri pentingnya ritus dan aspek-aspek sosial setiap agama, namun filsafat perennial mengajarkan bahwa dibalik hal tersebut terdapat satu tradisi asal. Dalam penelitiannya tentang filsafat perennial, nasr kemudian

31 Seyyed Hossein Nasr, Islamic Life and Thought (New York: State University of New York, 1981), 16-17.

32 Seyyed Hossein Nasr, God (New York: State University of New York, 1987), 311-113.

${ }^{33}$ Hidayat and Nafis, Agama Masa Depan: Perspektif Filsafat Perennial. 
menemukan bahwa filsafat perennial memiliki cabang-cabang yang berhubungan dengan kosmologi, antropologi, seni dan lain sebagainya, namun dalam jantungnya terletak metafisika murni. Jika kata metafisika diartikan sebagai pengetahuan mengenai yang kudus (Scientia Sacra), maka konsep tersebut jangan dikacaukan dengan konsep yang sama dalam filsafat barat pasca abad pertengahan. Nasr menegaskan metafisika yang dipahami dalam perspektif filsafat perennial merupakan suatu pengetahuan ilahiyah yang sesungguhnya, bukan merupakan sesuatu yang akan berubah dengan berubahnya gaya budaya suatu zaman atau munculnya penemuanpenemuan baru dari pengetahuan dunia material. $^{34}$

Mengenai kearifan tradisional, banyak nama yang telah diberikan seperti al-bikmah alilahiyah (kearifan Tuhan) merupakan nama dalam tradisi islam atau scientia sacra, dalam membahas mengenai tradisi Islam seperti yang dikatakan Nasr:

"Penyampaian kebenaran atau prinsipprinsip Ilahi yang diwahyukan kepada manusia dan seluruh alam beserta aplikasinya dalam berbagai realitas melalui beberapa figur yang dipilih, seperti rasul, avatar, logos ataupun figur lainnya, penyampaian tersebut mencakup aspek hukum dan struktur sosial, seni, simbolisme serta berbagai cabang ilmu pengetahuan." 35

Dari kutipan di atas, Nasr menjelaskan bahwa tradisi itu berhubungan dengan berbagai hal baik itu dalam pengetahuan, tata cara, praktek, hukum-hukum, maupun bentuk-bentuk baik itu secara lisan maupun tulisan. Dalam teks lain Nasr menyebutkan tradisi sebagai:

"Sesuatu yang disampaikan kepada manusia melalui wahyu merupakan

${ }^{34}$ Hidayatullah, "Konsep Ilmu Pengetahuan Syed Hussein Nashr: Suatu Telaah Relasi Sains Dan Agama."

35 Seyyed Hossein Nasr, Knowledge and the Sacred, Gifford Lectures (New York: State University of New York Press, 1989), 64. sesuatu yang sakral baik itu dalam pengungkapan maupun pengembangan peran sakral itu dalam sejarah kemanusiaan tertentu, yang diaplikasikan dalam satu cara baik itu dalam hubungan horizontal dengan sumber mata rantai maupun hubungan vertikal yang menghubungkan setiap denyut tradisi kehidupan yang sedang diperbincangkan dengan realitas transenden dibalik sejarah." ${ }^{\circ 6}$

Secara keseluruhan Nasr memberi kesimpulan bahwa pada prinsipnya keabadian dalam berbagai situasi ruang dan waktu adalah menjadikan tradisi sebagai kebenaran yang kudus, tetap, kebijaksanaan yang abadi, serta penerapan yang berkesinambungan

Nasr memberi penjelasan mengenai perpaduan makna tradisi dalam khazanah Islam. Menurutnya seluruh aspek agama beserta percabangannya merupakan tradisi, kata yang sudah dipahami secara umum dan sudah menjadi tradisi dalam arti sesuatu yang sudah didasarkan pada model-model yang sakral disebut al-Sunnah, dan seperti yang terlihat pada sufisme, terdapat rantai yang menghubungkan setiap periode dan tahap perkembangan pemikiran dan kehidupan didunia tradisional disebut al-Silsilah. Nasr menggambarkan tradisi diibaratkan sebagai pohon, akarnya adalah wahyu yang dari akar tersebut tumbuh batang dan ranting-rantingnya yang terus berkembang sepanjang zaman, di jantung pohon adalah agama, barakah dari wahyu ilahi yang memungkinkan pohon itu untuk terus hidup merupakan saripatinya. ${ }^{37}$

Terdapat dua unsur utama dari penjelasan di atas yaitu kebenaran yang berhubungan dengan pengetahuan dan kehadiran berhubungan dengan yang wujud. Kebenaran dan kehadiran merupakan wujud penyelamatan dari yang mutlak dalam perenialisme, keduanya saling memiliki keterkaitan satu sama lain dan tidak dapat berdiri

36 Seyyed Hossein Nasr, Tradisional Islam in The Modern World (London: Kegan Paul International, 1989), 13.

${ }^{37}$ Nasr, Tradisional Islam in The Modern World. 
sendiri inilah yang dinamakan sifat ganda dari pancaran Tuhan. ${ }^{38}$

Dilihat dari yang telah dijelaskan tersebut, dalam pengamatan Nasr masyarakat Barat telah kehilangan visi keilahian dalam masa perkembangannya, penglihatannya sudah buram dalam melihat realitas kehidupan. Hal ini disebabkan karena masyarakat modern mengalami kehilangan fungsinya sehingga mengakibatkan mereka berada di pinggiran eksistensi, pengetahuannya yang terpecah-pecah berdampak oada ketidak mampuannya melihat alam sebagai kesatuan tunggal. ${ }^{39}$

Relevansi pemikiran Nasr tentang filsafat perennial yaitu mengenai kearifan tradisional dalam Islam. Pemikiran Nasr muncul untuk merespon krisis yang dialami manusia modern. Peradaban modern telah gagal mencapai tujuannya, khususnya di Barat dan kemudian di tumbuh kembangkan dalam dunia Islam, kehidupan modern semakin mereduksi integritas manusia. Dengan demikian Nasr memberi solusi alternatif dengan mengkaji filsafat perennial sebagai solusi untuk menghadapi segala persoalan yang muncul setelah melihat krisis kemanusiaan yang terjadi di zaman modern.

\section{NESTAPA MANUSIA MODERN}

Abad ke 17 Masehi menandai awal kemenangan modernisme atas dogmatisme agama seperti: rasionalisme, empirisme, dan positivisme dunia modern di Barat. Dalam epistimologi terkandung hubungan antara rasionalisme, empirisme dan positivisme yang melahirkan metode ilmiah, dimana dalam melihat kebenaran sesuatu hanya diperhitungkan dari sudut yang bersifat pengindraan dan kebendaan saja tanpa memperhatikan sudut metafisika. Hal ini terjadi karena kehidupan telah diwarnai oleh paham sekularisme, rasionalisme, empirisisme, cara berpikir dikotomi, desakralisasi, pragmatisme, dan menghiraukan kebenaran metafisis. Pandangan

${ }^{38}$ Nasr, Knowledge and the Sacred.

39 Seyyed Hossein Nasr, Islam and the Plight of Modern Man (London dan New York: Longman, 1975), 15. hidup inilah akhirnya yang mewarnai peradaban Barat Modern. ${ }^{40}$

Perkembangan dalam bidang sains modern inilah yang telah merubah pandangan hidup dan memberikan kontribusi besar terhadap sekularisasi. Hal ini membuat manusia di zaman modern mengeksploitasi, memperlakukan alam dan menikmatinya sesuai dengan kehendaknya sendiri tanpa memperhatikan kewajiban dan tanggung jawab. Hal ini terjadi disebabkan oleh visi sekularisasi yaitu pengosongan nilai-nilai spiritual dalam memandang alam semesta, yang telah menciptakan berbagai bentuk krisis dizaman modern baik itu krisis spiritual maupun kehidupan sosial, inilah dampak dari sekularisasi sebagai inti modernisme. ${ }^{41}$

Bentuk-bentuk kekacauan yang ditimbulkan oleh manusia di zaman modern adalah terjadinya benturan antara penemuanpenemuan yang disertai dengan tipu daya manusia dalam bentuk teknologi dengan kultur mereka, maupun dampak mengerikan dan menghancurkan lingkungan. Tanpa disadari manusia modern telah membakar tangan mereka sendiri dengan api yang telah mereka nyalakan karena mereka telah lupa siapa diri mereka sebenarnya. Seperti yang dilakukan Faust, setelah dia menjual jiwanya demi memperoleh kekuasaan terhadap lingkungan, ia menciptakan situasi lingkungan menjadi tidak terkontrol dan berubah menjadi pencekikan terhadap lingkungan tersebut, selanjutnya tidak hanya berubah menjadi kehancuran ekonomi tetapi juga terjadinya perbuatan bunuh diri. ${ }^{42}$

Masalah penghancuran lingkungan oleh teknologi, krisis ekologi, dan lain sebagainya bersumber dari penyakit pelupa yang diderita oleh manusia modern. Mereka lupa siapa diri mereka sebenarnya karena mereka hidup dipinggir lingkaran eksistensinya sendiri. Maka terjadilah serangkaian keterpurukan yang menyebabkan

\footnotetext{
40 Irawan, "Tasawuf Sebagai Solusi Krisis Manusia Modern: Analisis Pemikiran Seyyed Hossein Nasr."

${ }^{41}$ Irawan.

${ }^{42}$ Nasr, Islam Dan Nestapa Manusia Modern.
} 
manusia semakin jauh dari pusat eksistensinya dan dari lingkungan kosmisnya ${ }^{43}$

Akibat yang ditimbulkan oleh perkembangan sains modern ini membuat manusia menjadi pemuja ilmu dan teknologi, tanpa disadari hal tersebut akan mengikis integritas kemanusiaannya, mereka terperangkap dalam sistem rasionalitas teknologi yang sangat tidak manusiawi. Hal ini dikarenakan manusia modern melakukan sesuatu yang tidak seharusnya mereka lakukan, menciptakan sebuah sains dan memperoleh data yang hanya dengan mengandalkan kekuatan akal dan indra semata tanpa mengikutsertakan sesuatu yang ada dibalik kekuatan tersebut yaitu Tuhan yang merupakan sang pemilik kehidupan, manusia modern mulai melupakan Tuhan dalam menjalani kehidupannya. $^{44}$

Bagaimanapun kita tidak bisa menemukan kecendrungan manusia modern untuk memecahkan permasalahan-permasalahannya tanpa menimbang faktor-faktor yang menjadi penyebab dari persoalan-persoalan tersebut. Secara umum hal ini sangat terlihat nyata didalam sains-sains yang diperkirakan dapat memberikan wawasan-wawasan mengenai sifat hakiki manusia yang khas. Manusia modern yang melakukan perlwanan kepada Tuhan, telah menciptakan sains yang tidak berdasarkan pada cahaya intelektual. ${ }^{45}$

Menurut Nasr, dilihat dari sudut pandang metafisik terdapat hubungan antara pengetahuan dan keberadaan, hal ini merupakan proses sekularisasi dan humanisasi yang terjadi di Barat yang menjadi pemicu sebuah proses terpisahnya pengetahuan dari keberadaan. ${ }^{46}$ Manusia di abad modern ini telah kehilangan rasa takjub yang berakibat pada hilangnya rasa suci. Hilangnya rasa suci dalam peradaban Barat menyebabkan terpisahnya ilmu dan etika. ${ }^{47}$

43 Nasr.

44 Nasr.

45 Nasr.

${ }^{46}$ Nasr, Knowledge and the Sacred.

${ }^{47}$ Seyyed Hossein Nasr, The Need for a Sacred Science (Surrey: Curzon Press, 1993), 82.
Seperti para pemikir lain yang melirik persoalan mengenai krisis terhadap sains dan peradaban modern, percaya bahwa Barat sedang mengalami krisis yang sejalan dengan proses sekularisasi. Nasr berusaha mengungkap titik lemah dari perkembangan sains Barat. Kritik nasr terhadap sains modern dapat membuka jalan untuk mengungkapkan konsepnya mengenai sains tradisional dan scientia sacra, yang diyakininya dapat dijadikan sebagai alternative dalam menyelesaikan krisis manusia modern. Kritik Nasr terhadap sains modern bertepatan dengan kritiknya terhadap modernitas yang ia anggap telah melanggar ajaran abadi dan universal yang dilestarikan oleh peradaban tradisional. ${ }^{48}$

Dari pemaparan di atas dapat dilihat bahwa antara aspek spiritual dan materi keduanya memiliki keterkaitan satu sama lain dan tidak dapat dipisahkan. Krisis spiritual yang dialami oleh manusia di zaman modern disebabkan karena mereka hanya memperhatikan aspek materi saja dalam menghadapi sesuatu tanpa memperhatikan aspek terpenting dari manusia itu sendiri yaitu aspek spiritual. ${ }^{49}$

\section{SUFISME SEBAGAI OBAT}

Seyyed Hossein Nasr merupakan seorang tokoh yang sangat memahami mengenai tradisitradisi Barat dan juga Timur, sehingga ia berupaya untuk dapat mengembalikan kebenaran yang suci kepada manusia sebagai sains sakral, seperti dalam ungkapannya:

"Tradisi mengungkapkan suatu kebenaran yang sakral, bersifat abadi, dan kebijaksanaan yang kekal, dapat diterapkan secara terus-menerus dan tidak mengalami perubahan dalam berbagai kondisi ruang dan waktu, meskipun peradaban dan juga tradisi di bumi mengalami suatu perubahan namun tradisi

48 Asfa Widiyanto, "Traditional Science and Scientia Sacra: Origin and Dimensions of Seyyed Hossein Nasr's Concept of Science," Intellectual Discourse 25, no. 1 (2017): 253.

${ }^{49}$ Nasr, Islam Dan Nestapa Manusia Modern. 
yang sakral tidak akan mengalami pembusukan dan akan terus berada dalam peradaban yang suci". ${ }^{50}$

Dalam bidang kajian Islam yang selalu memiliki daya tarik untuk dikaji dan dipelajari adalah kajian mengenai tasawuf. Kajian tasawuf banyak dikaji oleh para ilmuan mulai dari kalangan muslim maupun orientalis. Para ilmuan memiliki definisinya tersendiri dalam mendefinisikan tasawuf, walaupun demikian, didalam tasawuf terdapat dua esensi dasar yang tidak bisa dilepaskan yaitu mengenai akhlak dan kebahagiaan. $^{51}$

Di abad modern Kemajuan dalam bidang ilmu pengetahuan dan juga teknologi tanpa disadari telah membawa manusia kepada hakikat yang nista. Manusia telah terlena dengan sesuatu yang bersifat materi dan hanya memberikan kesenangan yang bersifat sementara sehingga membuat mereka terlupa dengan sesuatu yang dapat memenuhi kebutuhan bathinnya yaitu spiritual, hal tersebut membuat mereka mengalami kekosongan jiwa dan memerlukan upaya mendesak untuk menyembuhkannya. Oleh sebab itu untuk memulihkan kembali kekosongan jiwa yang dialami oleh manusia modern Nasr memberikan tawaran untuk menghidupkan kembali nilai-nilai tasawuf sebagai jalan untuk manusia modern mendekatkan diri kepada Allah, Nasr juga menegaskan, untuk memahami sufisme dalam Islam harus dipahami melalui sumber yang merupakan pedoman bagi imat Islam yaitu alQur'an dan Hadis. ${ }^{52}$

Ciri khas dari pemikiran Nasr tentang tasawuf salah satunya adalah mengenai hubungan antara dimensi syari'ah (eksoterik) dengan dimensi tasawuf (esoterik), eksoterik merupakan sesuatu sesuatu yang berpijak pada hakikat dan esoterik merupakan sesuatu yang berkaitan dengan dimensi batin, kedua hal ini sangat

\footnotetext{
${ }^{50}$ Nasr, Tradisional Islam in The Modern World.

${ }^{51}$ Irawan, "Tasawuf Sebagai Solusi Krisis Manusia Modern: Analisis Pemikiran Seyyed Hossein Nasr."

52 Widayani, "Pemikiran Sayyid Hossein Nasr Tentang Filsafat Perennial."
}

penting bagi kehidupan manusia. Menurut Nasr untuk mempraktekkan ajaran tasawuf seseorang harus terlebih dahulu melaksanakan ajaran-ajaran syari'ah dengan benar. Nasr menjelaskan pentingnya hubungan antara syari'ah dan tasawuf,

"Dimensi lahir dan dimensi bathin keduanya memiliki keterkaitan yang erat, dimensi lahir dibutuhkan oleh manusia sebagai dasar atau alas untuk berpijak dalam mencapai dimensi batin. Pengalaman ilahiah bisa tercapai oleh manusia jika keadaan batinnya sudah bersih dari segala hal yang dapat menghambatnya menuju pada Tuhan, disinilah pentingnya menjaga hubungan antara dimensi eksoterik dan juga dimensi esoterik." 53

Nasr juga mengungkapkan:

"Sufisme memungkinkan penuntunan perilaku karena menuntun para pencari dalam perjalanan batin dalam perjalanan di jalan Hukum Suci, atau syari'ah, yang merupakan perjalanan dalam perjalanan hidup, sementara kehidupan itu sendiri adalah perjalanan dalam perjalanan semua makhluk dalam kembalinya mereka ke Sumber." ${ }^{54}$

Penjelasan Nasr ini memilki kaitan yang erat dengan sebuah teori nya terdahulu yaitu teori mengenai rim dan axis. Kemudian teori tersebut ia terapkan dalam tasawuf yang menjelaskan bahwa pada hakikatnya dunia ini terdiri dari dua aspek yaitu aspek lahir dan aspek batin, yang dapat menggiring manusia dari pinggiran eksistensi menuju kepada titik pusat yang segala sesuatu berputar mengelilinginya (Tuhan). Maka dengan cara inilah manusia dapat kembali kepada fitrahnya. ${ }^{55}$

Mengenai teori rim dan axis, kedua istilah ini diartikan pusat dan lingkaran atau dalam

${ }^{53} \mathrm{Nasr}$, Islamic Life and Thought.

${ }^{54}$ Seyyed Hossein Nasr, The Garden of Truth; The Vision and Promise of Sufism, Islam's Mystical Traditional (New York: Harper Collins Publishers, 2008), 7.

55 Al-Ghazali, Ibya' Ulum Al-Din (Beirut: Dar alma'rifah, 1980), 47-51. 
bahasa al-Qur'an disebut yang batin, yang merupakan kualitas dasar. Allah SWT adalah merupakan pusat tertinggi baik itu dalam bentuk zahir maupun batin, seperti dalam sebuah lingkaran, Tuhan merupakan titik pusat lingkaran yang segala sesuatu berputar mengelilinginginya, padanya terletak kebenaran yang menjadi sumber tasawuf dan syari'at, keduanya dijadikan Tuhan sebagai sumber kebenaran sementara Lingkaran adalah syari'at, sesuatu yang membentuk masyarakat muslim. Setiap muslim yang meyakini keberadaan Tuhan maka dia adalah titik yang berada didalam lingkaran, manusia yang berada pada titik didalam lingkaran, mereka merupakan seseorang yang menerima syari'at dengan benar, karena hanya dengan mempelajari syari'ahlah sehingga manusia dapat dengan mudah mencari jalan untuk menuju pusat atau memungkinkan terbukanya pintu kehidupan spiritual. Menurut Nasr manusia yang suci adalah manusia yang memandang Tuhan sebagai yang zahir dan yang batin. ${ }^{56}$

Lebih lanjut untuk memahami hal yang bersifat esoterik dan juga eksoterik, penulis akan sedikit menjelaskan mengenai hubungan keduanya, unsur eksoterik (syari'at) seperti halnya melaksanakan shalat, zakat, puasa, haji, ritual zikir dan lain-lain, sedangkan esoterik (hakikat) berupa pencapaian nilai-nilai kesabaran, kezuhudan, hingga ma'rifat. Jika ditemukan seseorang yang mengaku ma'rifat tanpa melaksanakan shalat dan ibadah wajib lainnya maka hal yang demikian merupakan suatu hal yang salah kaprah. Itulah hubungan erat antara dimensi eksoterik dan juga esoterik, keduanya tidak dapat dipisahkan dan saling berkaitan satu dengan yang lain.

$$
\text { Bagi Nasr, seseorang yang }
$$
mempraktekkan tasawuf tanpa menjalani syari'at ibarat sayur tanpa garam. Hanya dengan mengamalkan syari'ah seseorang dapat menulusuri jalan thariqat yang akhirnya dapat

\footnotetext{
${ }^{56}$ Ridwan, Dasar-Dasar Epistemologi Islam.
}

menemukan kebenaran yang merupakan jantung dari segala sesuatu. ${ }^{57}$

Teori selanjutnya adalah teori Kesatuan dan Insan Kamil, Pandangan sufistik Nasr berkisar pada ajaran dasar kesatuan (tauhid). Ajaran tentang kesatuan dan insan kamil telah membangun poros seluruh metafisika dari ajaran sufi Nasr. Bagi Nasr, tasawuf tidak disebut sebagai mistisisme Islam sebab istilah tersebut mengandung pengertian yang mendorong manusiahanya pasrah pada Tuhan sehingga menganggap segala usaha untuk mencukupi kebutuhan hidup tidak penting. ${ }^{58}$

Dari sinilah Nasr memandang untuk menjawab persoalan-persoalan yang sedang dihadapi oleh masyarakat modern tasawuf dan nilai-nilai tradisional lainnya lah yang cocok untuk menghadapi segala persoalan yang kian mendesak. Tasawuf dapat mengisi kembali kekeringan spiritual yang dirasakan manusia.

Setelah menjelaskan mengenai tasawuf tersebut maka timbullah pertanyaan bagaimana caranya untuk menghidupkan kembali nilai-nilai tasawuf dalam masyarakat modern, dalam hal ini Nasr mengungkapkan ada tiga cara yang bisa dilakukan yaitu:

Pertama, mempraktekkan ajaran-ajaran tasawuf secara rutin. Menurut nasr karena cara pertama ini memberi syarat untuk melakukan penyerahan pada disiplinnya maka cara ini hanya diperuntukkan untuk sebagian orang saja. Pada tahapan pertama ini dalam prakteknya, melakukan seperti yang terdapat pada hadis Nabi; "Matilah kamu sebelum kamu benar-benar". Maksud hadis ini yaitu setiap orang yang ingin mempraktekkan cara yang pertama ini seseorang diharuskan untuk mempraktekkan pada dirinya layaknya seperti ia telah mati dalam arti mematikan dirinya sebelum ia dimatikan, hal ini dilakukan sebelum kembali dilahirkan secara spiritual. Cara untuk melakukan hal tersebut adalah membatasi kesenangan dan menahan nafsunya dari godaan dunia materi. 
Langkah selanjutnya adalah mensucikan batin dengan cara melakukan praktek-praktek ibadah seperti rajin melaksanakan shalat, mengaji, berdo'a dan lain sebagainya seperti ibadah yang dilaksanakan oleh para sufi pada umumnya. ${ }^{59}$

Kedua, dengan cara menyuguhkan Islam dalam bentuk yang menarik yaitu menyuguhkan dakwah Islam kepada masyarakat di timur maupun di barat dalam bentuk yang menarik dengan cara memperlihatkan keharmonisan tasawuf sebagai aspek spiritual dalam Islam. Cara ini sudah berhasil diterapkan di Indonesia, Afrika Barat dan India. Di dunia Barat dalam aktifitas dan metodenya tentu berbeda dengan Nagaranegara tersebut, namun pada esensinya mereka adalah sama. Yakni dalam menghadapi krisis kekeringan spiritual dan hilangnya makna kehidupan yang sedang terjadi di Barat, tasawuf membuka peluang yang sangat besar untuk menghadapi permasalahan yang tengah melanda manusia modern. ${ }^{60}$

Ketiga, tasawuf dapat dijadikan sebagai alat bantu untuk menyadarkan masyarakat di timur maupun di barat dari tidurnya dan membantu mereka untuk mengingat kembali mengenai makna hidup yang sesungguhnya. Tasawuf dapat menghidupkan kembali aspekaspek kehidupan rohani di Barat maupun di Timur yang selama ini sudah dilupakan, hal ini dapat dilakukan sebagai cara untuk menyadarkan manusia modern karena tasawuf merupakan sesuatu yang kaya dengan ajaran-ajaran yang mencakup metafisik, kosmologi, serta psikologi religious yang sebelumnya di Barat belum pernah mempelajarinya. ${ }^{61}$ Setelah melihat krisis yang dialami dalam kehidupan manusia modern Nasr sangat yakin tasawuf dapat menjawab dan memberi solusi terhadap permasalahan tersebut.

Untuk mengembangkan ajaran-ajaran tasawuf di abad modern, tasawuf juga harus dapat disesuaikan dengan gaya hidup masyarakat di abad modern agar masyarakat dengan mudah

\footnotetext{
${ }^{59}$ Nasr, Islam Dan Nestapa Manusia Modern.

${ }^{60}$ Nasr.

${ }^{61} \mathrm{Nasr}$.
}

menerima dan beradaptasi dengan ajaran-ajaran tasawuf, seperti halnya manusia tetap bisa menjalani aktifitas sosialnya namun tidak meninggalkan kewajibannya kepada yang maha kuasa, nilai-nilai tasawuf tetap bisa mereka praktekkan baik itu dalam dunia kerja maupun aktifitas-aktifitas lainnya.

Aktifitas bertasawuf juga dapat dikreasikan dengan mendengarkan musik yang bernuansa islami, ini merupakan salah satu sarana yang banyak mendapat respon positif dari masyarakat. Rata-rata dari masyarakat gemar mendengarkan musik, untuk menggiring kesenangan masyarakat dalam mendengarkan musik agar dapat memberikan manfaat dan bukan hanya untuk memenuhi kesenangan tanpa makna semata akan lebih baik jika musik yang didengarkan diiringi pesan-pesan Islami, tentunya kegiatan yang hanya untuk bersenang-senang semata beralih kepada kegaiatan yang memberikan nuansa religius. ${ }^{62}$

\section{PENUTUP}

Seyyed Hossein Nasr merupakan seorang intelektual yang kemampuannya sudah tidak diragukan lagi. Ia memiliki buah pemikiran yang sangat beragam di antara pemikiran yang telah dicetuskan oleh Nasr adalah mengenai spiritualitas Islam. Pada masa beberapa kehidupan di dunia Islam telah dipengaruhi oleh kehidupan barat dan mengalami westernisasi, pemikiran Nasr mengenai keaagamaan secara objektif mengandalkan adanya realitas suprim yang personal sedangkan agama mengandalkan kemampuan manusia dalam menerima kebenaran wahyu dalam arti dipandang secara subjektif.

Dalam filsafat perenial yang dimaksud oleh Nasr mengenai filsafat keabadian atau kearifan tradisional dalam Islam. Pemikirannya mengenai filsafat perenial merupakan reaksi yang mengganggu pikirannya di saat ia melihat krisis

62 Muhammad Taufik and Noor Fadhli Marh, "Pesan Dakwah Melalui Musik Islami," FUADUNA : Jurnal Kajian Keagamaan Dan Kemasyarakatan 2, no. 1 (June 30, 2018): 2, https://doi.org/10.30983/fuaduna.v2i1.2021. 
yang terjadi pada manusia di abad modern. Peradaban modern yang berkembang di Timur maupun di Barat menurut Nasr telah gagal dalam meraih tujuannya. Oleh sebab itu, filsafat perenial yang dimunculkan oleh Nasr ini merupakan sebuah respon terhadap apa yang sedang terjadi ditengan masyarakat modern.

Menurut Nasr untuk menghadapi persoalan ini nilai-nilai tradisional seperti tasawuf perlu untuk dihidupkan kembali, ini merupakan sebuah alternatif yang ditawarkan oleh Nasr untuk mengobati krisis yang terjadi ditengah masyarakat. Menurut Nasr krisis-krisis eksistensialisme maupun spiritual yang dialami oleh manusia modern adalah karena manusia melupakan Tuhan demi mempertegas eksistensi dirinya sehingga hal tersebut menjadi bumerang dalam diri mereka sendiri dan membuat mereka berada di pinggiran eksistensi, sehingga hal ini membuat mereka lupa siapa diri mereka dan lupa terhadap Tuhan yang merupakan sumber dari segala yang ada. Fenomena ini tidak hanya terjadi di Barat tetapi juga terjadi di Timur.

\section{DAFTAR KEPUSTAKAAN}

Al-Ghazali. Ibya' Ulum Al-Din. Beirut: Dar alma'rifah, 1980.

Bakker, Anton, and A. Charris Zubair. Metodologi Penelitian Filsafat. Pustaka Filsafat. Yogyakarta: Penerbit Kanisius, 1994.

Busyro, Busyro, Aditiya Hari Ananda, and Tarihoran Sanur Adlan. "Moderasi Islam (Wasathiyyah) Di Tengah Pluralisme Agama Indonesia." FUADUNA: Jurnal Kajian Keagamaan Dan Kemasyarakatan 3, no. 1 (November 2019): https://doi.org/10.30983/fuaduna.v3i1.115 2.

Harahap, Jaipuri. "Sayyed Hossein Nasr Tentang Filsafat Perennial Dan Human Spiritualitas." Aqlania 8, no. 2 (December 2017): 73.

Haryati, Tri Astutik. "Modernitas Dalam Perspektif Seyyed Hossein Nasr." Jurnal Penelitian 8, no. 2 (2012). https://doi.org/10.28918/jupe.v8i2.84.

Hidayat, Komaruddin, and M. Wahyuni Nafis. Agama Masa Depan: Perspektif Filsafat Perennial. Jakarta: Paramadina, 1995.
Hidayatullah, Syarif. "Konsep Ilmu Pengetahuan Syed Hussein Nashr: Suatu Telaah Relasi Sains Dan Agama." Jurnal Filsafat 28, no. 1 (February 2018): 113. https://doi.org/10.22146/jf.30199.

Irawan, Dedy. "Tasawuf Sebagai Solusi Krisis Manusia Modern: Analisis Pemikiran Seyyed Hossein Nasr." Tasfiyah 3, no. 1 (February 2019): https://doi.org/10.21111/tasfiyah.v3i1.2981

Kartanegara, Mulyadhi. Gerbang Kearifan: Sebuah Pengantar Filsafat Islam. Jakarta: Lentera Hati, 2006.

Kuswanjono, Arqom. "Filsafat Perennial Dan Rekonstruksi Pemahaman Keberagamaan." Jurnal Filsafat Special Ed (1997): 96-108. https://doi.org/https://doi.org/10.22146/j f.31778.

Maksum, Ali. Tasawnf Sebagai Pembebasan Manusia Modern: Telaah Signifikansi Konsep "Tradisionalisme Islam" Sayyed Hossein Nasr. Yogyakarta: Pustaka Pelajar, 2003.

Nasr, Seyyed Hossein. Antara Tuhan, Manusia Dan Alam. Yogyakarta: IRCiSoD, 2003.

. God. New York: State University of New York, 1987.

- Islam and the Plight of Modern Man. London dan New York: Longman, 1975.

- Islam Dan Nestapa Manusia Modern. Bandung: Pustaka, 1983.

- Islamic Life and Thought. New York: State University of New York, 1981.

- Knowledge and the Sacred. Gifford Lectures. New York: State University of New York Press, 1989.

- The Garden of Truth; The Vision and Promise of Sufism, Islam's Mystical Traditional. New York: Harper Collins Publishers, 2008.

- The Need for a Sacred Science. Surrey: Curzon Press, 1993.

. Tradisional Islam in The Modern World. London: Kegan Paul International, 1989.

Ridwan, Ahmad Hasan. Dasar-Dasar Epistemologi Islam. Bandung: CV Pustaka Setia, 2011.

Rusdin. "Kebenaran Agama Dalam Filsafat Perennial (Perspektif Seyyed Hossein Nasr)." Rausyan Fikr 14, no. 2 (2018).

Supriatna, Fitri Siska, and Salman Husain. "Kontribusi Filsafat Perenial Sayyed Hossein Nasr Terhadap Sains Modern." In Prosiding 
Konferensi Integrasi Interkoneksi Islam Dan Sains, 2:177-83, 2020.

Taufik, Muhammad, and Noor Fadhli Marh. "Pesan Dakwah Melalui Musik Islami." FUADUNA: Jurnal Kajian Keagamaan Dan Kemasyarakatan 2, no. 1 (June 30, 2018): 1. https://doi.org/10.30983/fuaduna.v2i1.202 1.

Taufik, Zulfan. Dialektika Islam Dan Humanisme. Tangerang Selatan: Onglam Books, 2015.

—. Wajah Perenial Sufisme Di Perkotaan Indonesia Kontemporer. Tangerang Selatan: Onglam Books, 2017.

Widayani, Hanna. "Pemikiran Sayyid Hossein Nasr Tentang Filsafat Perennial." ELAFKAR: Jurnal Pemikiran Keislaman Dan Tafsir Hadis 1, no. 6 (2017): 55-60.

Widiyanto, Asfa. "Traditional Science and Scientia Sacra: Origin and Dimensions of Seyyed Hossein Nasr's Concept of Science." Intellectual Discourse 25, no. 1 (2017): 249-74. 